\title{
Assessment of Maxillary Premolar Region in Relation to Maxillary Sinus Floor and Buccal Bone Plate: A Cone Beam Computed Tomography Study
}

\author{
Evaluación de la Región Premolar Maxilar en Relación con el Piso del Seno Maxilar \\ y la Tabla Osea Vestibular: Estudio de Tomografía Computarizada de haz Cónico
}

\author{
Ramón Fuentes ${ }^{1,2}$; Manuel Arellano-Villalón ${ }^{1,2}$; Natalia Soto-Faúndez ${ }^{3}$; Alain Arias ${ }^{1,2,4}$; \\ Ignacio Montiel'; Eduardo Borie ${ }^{1,2}$; Ivonne Garay ${ }^{1}$ \& Fernando Dias ${ }^{1,2}$
}

\begin{abstract}
FUENTES, R.; ARELLANO-VILLALÓN, M.; SOTO-FAÚNDEZ, N.; ARIAS, A.; MONTIEL, I.; BORIE, E.; GARAY, I. \& DIAS, F. Assessment of maxillary premolar region in relation to maxillary sinus floor and buccal bone plate: a cone beam computed tomography study. Int. J. Morphol., 37(3):1079-1084, 2019.
\end{abstract}

SUMMARY: The maxillary sinus floor location and the buccal bone plate are factors to be considered in the long-term success with implant treatments mainly in the premolar region. the aim of this study was to establish morphometric characteristics of the buccal cortical bone $(\mathrm{BCB})$ thickness of maxillary premolars and its relation to maxillary sinus floor through CBCT. In this study 350 first and second maxillary premolars were analyzed from $110 \mathrm{CBCT}$ images and the buccal cortical bone (BCB) was measured in a coronal view at the major axis level of each premolar. In addition, in 200 first and second maxillary premolars CBCT images were measured the distance from premolar apex to maxillary sinus floor (MSF) in both frontal and sagittal plane. The type of relationship between the apex and MSF was classified according to Ok et al. (2014). The second premolar was observed with higher values of BCB (p<0.001). In first premolar, higher values were observed in the male sex $(\mathrm{p}>0.05)$. In second premolar, only significantly higher values were observed in the male sex in MA-MB-MC (p>0.05). Regarding to MSF and its relation to premolar roots, it was observed that $10 \%$ of the sample was classified as type I, $19 \%$ as type II, $55.5 \%$ as type III and $15.5 \%$ as type IV. The BCB of the upper premolar region is thicker in the apical region and decreases toward the coronal region. Almost $50 \%$ of apex of second premolars are closely and risky related MSF (Type I and II).

KEY WORDS: Premolars; Maxillary sinus floor; Buccal bone plate; Cone beam-computed tomography.

\section{INTRODUCTION}

The maxillary sinus floor location and the buccal bone plate are factors to be considered in the long-term success with implant treatments (Vera et al., 2012), mainly in the premolar region. The proximity of the maxillary sinus to the apex of the premolars as well as the thickness of buccal cortical bone (BCB) may determine surgical planning with dental implants as well as the treatment time.

In clinical practice, the integrity of the $\mathrm{BCB}$ is a directly related factor with the soft tissues and consequently, with the aesthetic results (Chen et al., 2007). Some authors consider acceptable thicknesses greater than $2 \mathrm{~mm}$ to decrease the amount of lost vestibular table (Buser et al.,
2007; Fuentes et al., 2015). While, other authors also describe that thicknesses greater than $1 \mathrm{~mm}$ are sufficient to achieve primary stability and are a prerequisite for favorable results in immediate placement of implants, in conjunction with filling bone with a low substitution rate (Holmes et al., 2015). However, thickness of the BCB in the maxillary region is reported to vary according to tooth location, sex, and age (Aktuna Belgin et al., 2017; Adiguzel et al., 2017). Park et al. (2013) described a progressive increase in the thickness of the BCB from the central incisor to the second premolar. However, in the premolar area, the data are limited to establish comparisons between vestibular thicknesses (Fayed et al., 2010). More specific and precise

\footnotetext{
${ }^{1}$ Department of Integral Adult Dentistry, Dental School, Universidad de La Frontera, Temuco, Chile.

${ }^{2}$ Research Center for Dental Sciences (CICO), Dental School, Universidad de La Frontera, Temuco, Chile.

${ }^{3}$ Dental School, Universidad de La Frontera, Temuco, Chile.

${ }^{4}$ Universidad Adventista de Chile, Chillán, Chile.

${ }^{5}$ Undergraduate student, Dental School, Universidad de La Frontera, Temuco, Chile.
} 
FUENTES, R.; ARELLANO-VILLALÓN, M.; SOTO-FAÚNDEZ, N.; ARIAS, A.; MONTIEL, I.; BORIE, E.; GARAY, I. \& DIAS, F. Assessment of maxillary premolar region in relation to maxillary sinus floor and buccal bone plate: a cone beam computed tomography study. Int. J. Morphol., 37(3):1079-1084, 2019.

data are needed to establish characteristics of the vestibular bone cortex of maxillary premolars for clinical dental application.

On the other hand, maxillary sinus floor have a direct relationship with the apex of premolars and by consequence with the implant position in cases of exodontia (Ok et al.). Knowledge of the morphometric relationship between the maxillary sinus floor (MSF) and the premolars is also of great interest for other dental treatments such as the development and improvement of new dental implant techniques, management of atraumatic exodontias, reduction of post-extraction complications (Kilic et al., 2010), procedures that involve the manipulation of MSF, the use of grafts (Pommer et al., 2012) or procedures that involve orthodontic movements, among others (Ryu et al., 2016).

Therefore, the aim of this study was to establish morphometric characteristics of the buccal cortical bone (BCB) thickness of maxillary premolars and its relation to maxillary sinus floor through CBCT.

\section{MATERIAL AND METHOD}

A cross-sectional descriptive study was performed in cone beam computerized tomography (CBCT) images available at the Dental Clinic of the Dental School of the Universidad de La Frontera (Temuco, Chile). The Ethical Scientific Committee (CEC) of the Universidad de La Frontera (Folio $n^{\circ} 72 / 2013$ ) has previously approved this study.

Inclusion criteria consisted of (1) men and women between 12 and 61 years old (2) with complete or incomplete permanent dentition with presence of premolars. Exclusion criteria consisted of (1) CBCT with distortion or alteration in the images, (2) patients with evidence of bone alterations at the measurement sites, and (3) premolars without complete root formation or anatomical structures difficult to measure.

The images were obtained from PAX Zenith 3D orthopantomographs (Vatech Co., Suwon, Korea) and analyzed in DICOM format by using EZ3D2009 (E-WOO Technology Co. Ltd., Yongin, Korea) software.

Buccal cortical bone measurement. In this study, 350 first and second maxillary premolars were analyzed from 110 CBCT images. The images obtained were analyzed thickness in intervals of $1 \mathrm{~mm}$, placing the images to be measured according to the following references:
- Sagittal view: the coronal axis must pass through the major axis of the tooth and the axial axis through the amelocementary junction (ACJ).

- Axial view: the horizontal axis should have a parallel palatal vestibular trajectory, the vertical axis parallel to the distal mesio-axis, and the intersection of the axes should remain in the center of the tooth at the height of the root canal of the tooth measured.

- Superior view: the sagittal axis is located on the longitudinal axis of the tooth vertically, and the axial axis is through the ACJ.

Using the coronal view in the CBCT, the following anatomical points were considered: (A1) vertex of the radicular apex; (A2) point resulting from the intersection between the projected tangent of point A1 and the vestibular table; (E1), the innermost point of the marginal crest of the buccal table; (E2), the most external point of the marginal crest of the vestibular table; $(\mathrm{C} 1)$ projected point in the vestibular table equidistant to $\mathrm{A} 1$ and $\mathrm{E} 1$; (C2) projected point in the most medial portion of the vestibular table parallel to $\mathrm{C} 1$; (B1) projected point in the vestibular table equidistant to $\mathrm{A} 1$ and $\mathrm{C} 1$; (B2) projected point in the most medial portion of the vestibular table parallel to B1; (D1) projected point in the buccal table equidistant from points $\mathrm{E} 1$ and $\mathrm{C} 1$; and (D2) projected point in the portion more medial of the vestibular table parallel to D1 (Fig. 1).

Statistical analysis. SigmaPlot 12.0 software (Systat Software, Inc, San Jose, CA, USA) was used for the statistical analysis. The Shapiro-Wilk test was used to determine the normality of the data. The study data analyzed had not normal distribution, thus the Kruskal-Wallis test and Dunn's post hoc test were used; these data were presented as median $(50 \%)$, low $(25 \%)$ and high $(75 \%)$. In addition, correlation tests were performed between the thickness of the buccal cortical bone of the premolar region and the age of the volunteers.

Maxillary sinus floor and its relation to premolar roots. The final sample for this assessment was 200 first and second maxillary premolars, in which was measured the distance from premolar apex to the closest point from MSF (Measure $\mathrm{A}^{\prime}$ ), and the depth from the middle of the line that join the alveolar crest to the maxillary sinus floor (measure B'). When the apex was inside the maxillary sinus, it was considered a negative measure (Fig. 2).

Both the frontal and sagittal plane were measured using a single cut in the longitudinal axis of the premolar root. In bi-radicular teeth the root closest to the MSF was 


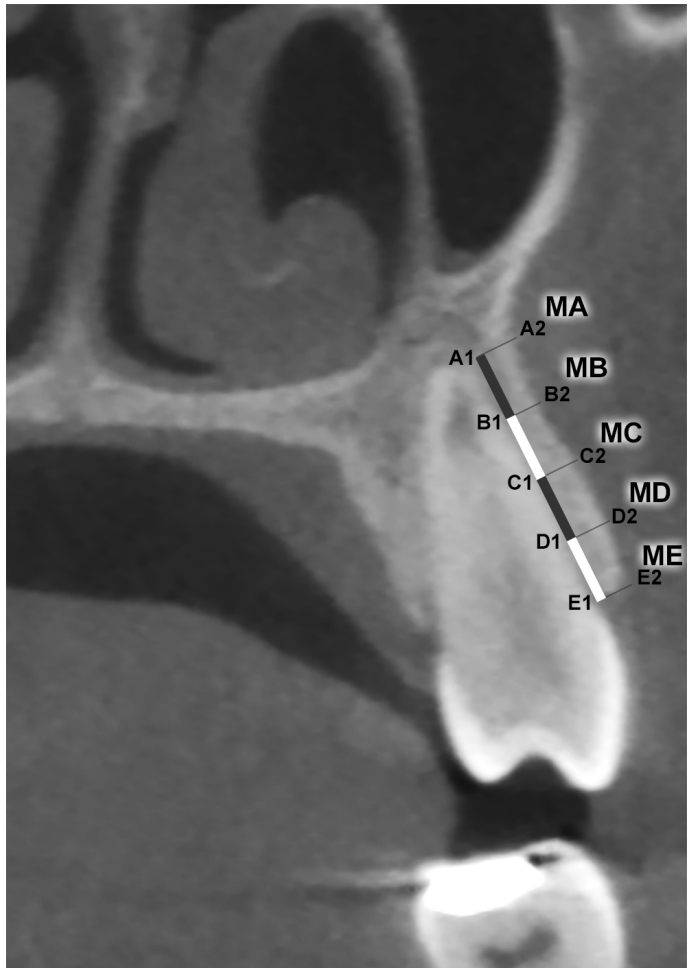

Fig. 1. Description of measurement points (MA, MB, MC, MD, ME), through points and lines of thickness equidistant from each other, from the tangent of the apex (MA) and the outermost points of the tooth, from the projection of the point in the most superficial cortical region of the buccal alveolar bone to the alveolar crest (ME).

measured. The type of relationship between the apex and the MSF was described previously by Ok et al. and was used in this research, as the following: Type I: the apex is above the MSF; Type II: the apex is at the same height of the MSF; Type III: the apex is below the MSF. It was added the type IV that was considered when the apex does not showed any type of relationship with the MSF in the established cut (Fig. 3). Finally, a frequency distribution was made by sex and age range.

Statistical analysis. A descriptive analysis of the data (normal distribution) using the mean and SD was determined. The t-test for independent samples was performed to compare the distances from the tooth to MSF by sex, ANOVA test of one factor to compare the relations between the teeth and MSF according to age range and Post-hoc Tukey test, Pearson's Chi-square test and intervals of $95 \%$ confidence for continuous quantitative variables. The statistical program IBM SPSS Statistics (v. 23.0) was used to analyze the data using $\mathrm{p}<0.05$.
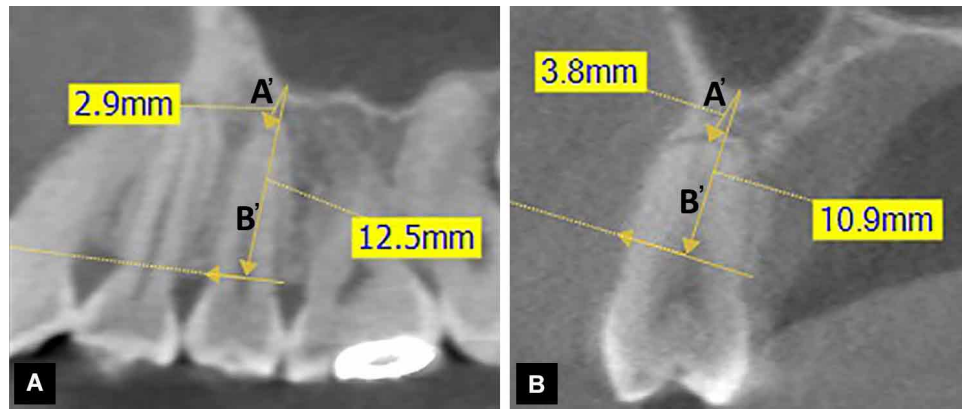

Fig. 2. Types of measurements made in the sagittal and frontal plane. A) Measurement in the sagittal plane. B) Measurement in frontal plane. A'Distance between closest point of MSF and dental apex. B'-Distance between the closest point of MSF and the half of the line joining the alveolar crests.
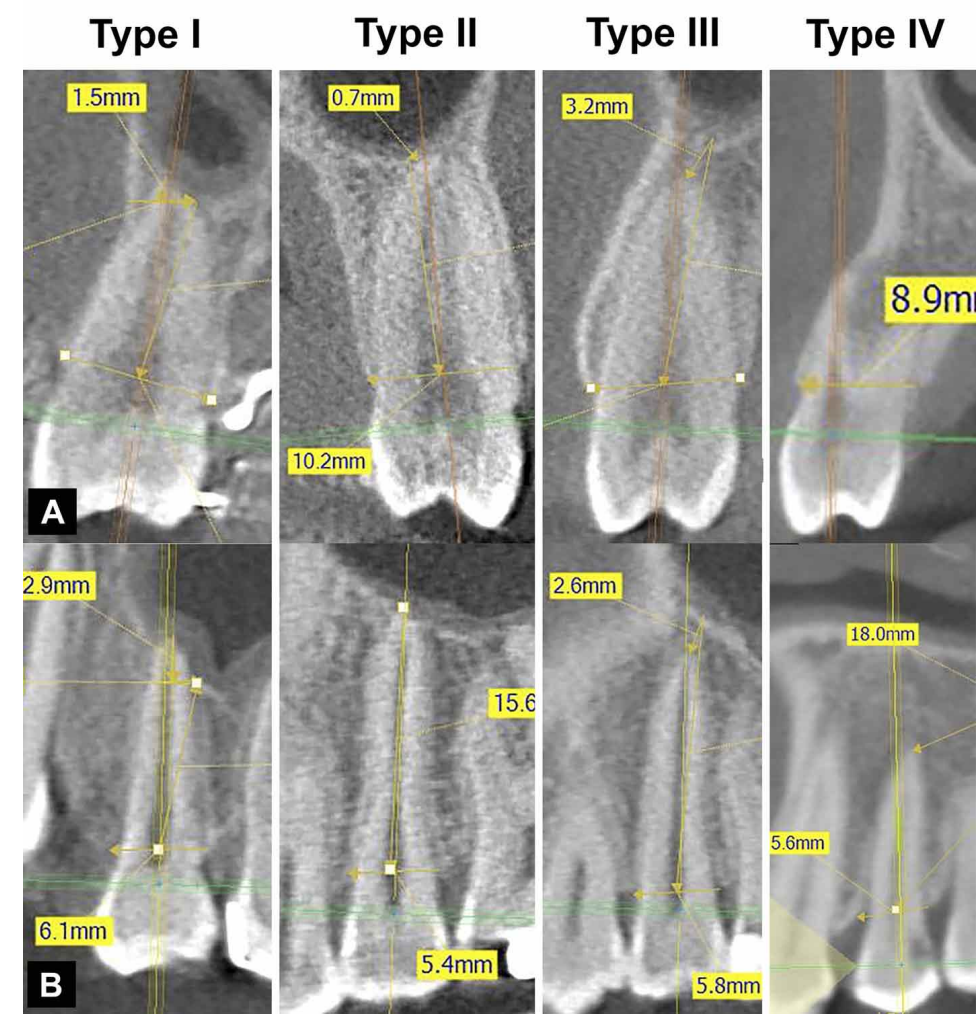

Fig. 3. Types of relations between premolar and MSF in frontal (A) and sagittal (B) planes.

\section{RESULTS}

Buccal cortical bone thickness. In all the analyses comparing the BCB thickness at different heights between the first and second premolar, significantly greater differences were identified for BCB thickness in the second premolar $(\mathrm{p}<0.001)$. Related to the comparison by sex in the first premolar region, significantly higher values were observed in the male sex, in all measured sites (MA-MB-MD-ME; $\mathrm{p}>0.05$ ), with the exception of MC (Fig. 4). At the second premolar region, it was identified only significantly higher values in the male sex in MA-MB-MC (p>0.05) (Fig. 4). 
First Premolar - Women

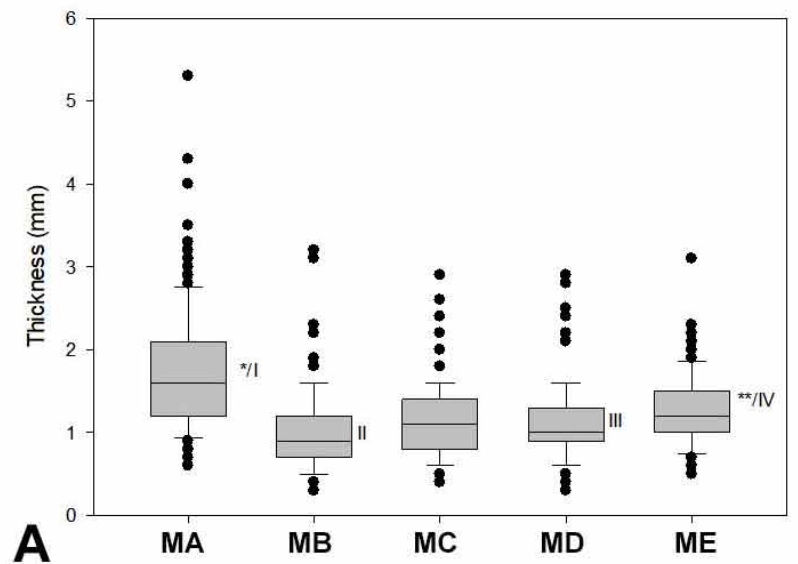

Second Premolar - Women

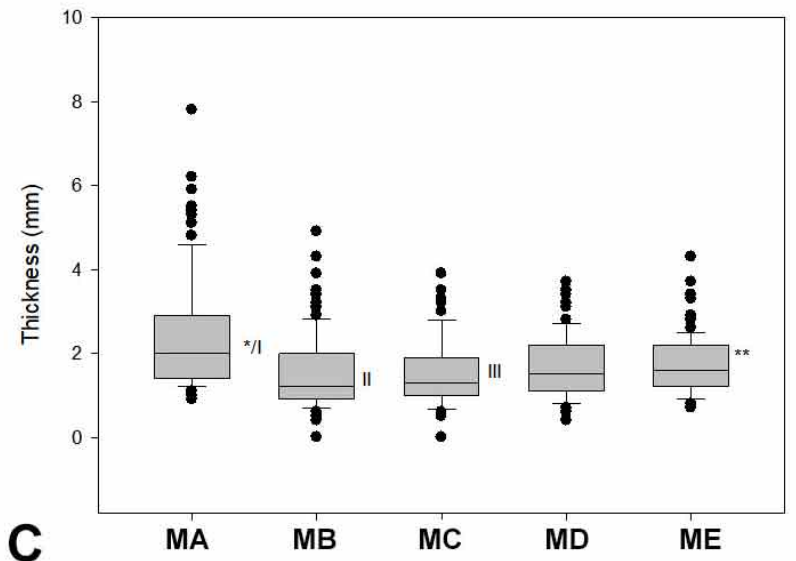

First Premolar - Men

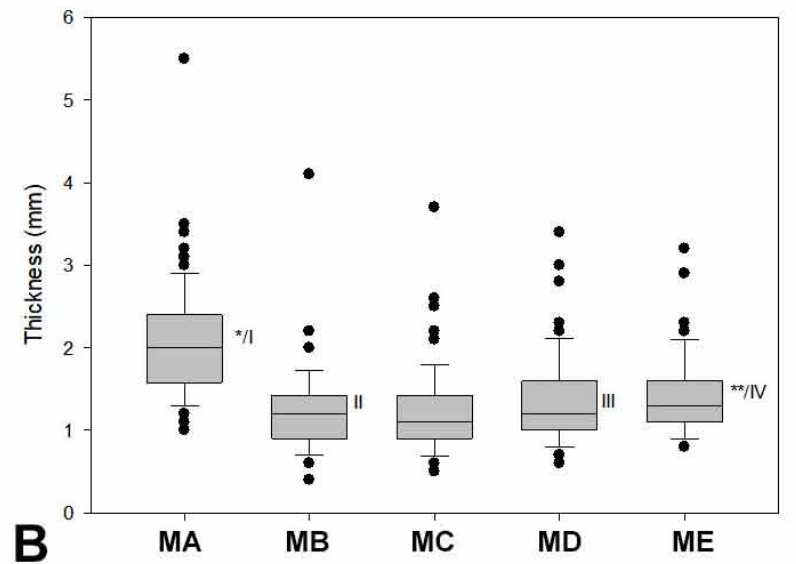

Second Premolar - Men

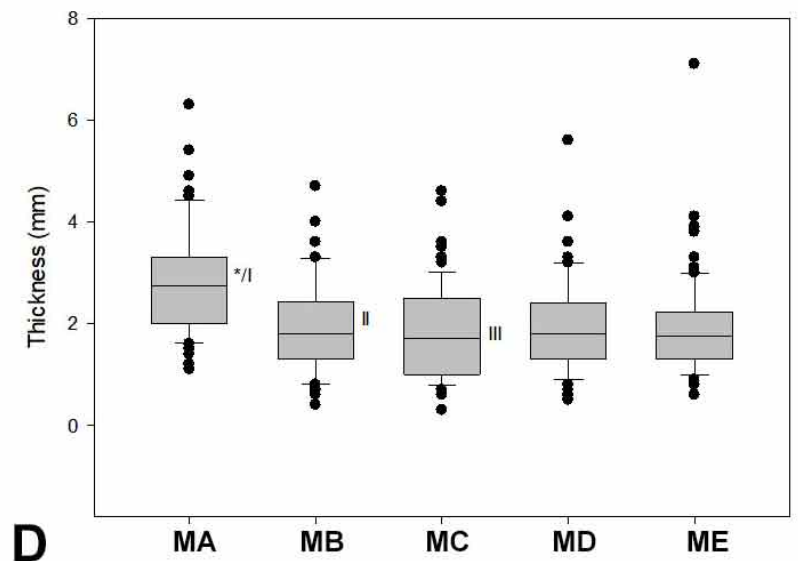

Fig. 4. BCB thickness in the region of maxillary premolars, comparing different levels. First maxillary premolar: A) In women, the thickness in MA was higher $(*, p<0.05)$ than all other levels evaluated; ME thickness was greater $(* *, p<0.05)$ than MB, MC, and MD. B) Among men, the MA thickness was greater $(*, p<0.05)$ than all other levels evaluated; ME thickness was greater $(* *, p<0.05)$ than MC. In the analysis of the data of the same levels in different sexes (between A x B), MA (I, p <0.001), MB (II, p <0.001), MD (III, p = $0.07)$, and $\mathrm{ME}(\mathrm{IV}, \mathrm{p}=0.034)$ were greater in men than in women. Second maxillary premolar C) In women, thickness in the MA was greater $(*, p<0.05)$ than all other levels evaluated; ME thickness was greater $(* *, p<0.05)$ than MB. D) In men, MA thickness was greater $(*, p<0.05)$ than all other levels evaluated. In the analysis of the data of the same levels in different sexes (between C x D), MA (I, p <0.001), MB (II, p <0.001), and MC (III, p = 0.029) were greater in men compared to women.

Maxillary sinus floor and premolar apex. It was observed that $10 \%$ of the sample was classified as type I, $19 \%$ as type II, $55.5 \%$ as type III and $15.5 \%$ as type IV (Table I).
Also, it was observed the lowest prevalence of type I classification in first premolars, while for second premolars was the type IV.

Table I. Frequency of type of relationship between premolar and MSF according to type of premolar. T-test for independent samples.

\begin{tabular}{lccccc}
\hline \multirow{2}{*}{ Tooth } & Type I & Type II & Type III & Type IV & Total \\
& $\mathrm{n}$ & $\mathrm{n}$ & $\mathrm{n}$ & $\mathrm{n}$ & $\mathrm{n}$ \\
\hline First premolar & 2 & 5 & 62 & 25 & 94 \\
Second premolar & 18 & 33 & 49 & 6 & 106 \\
Total & $20(10 \%)$ & $38(19 \%)$ & $111(55.5 \%)$ & $31(15.5 \%)$ & $200(100 \%)$ \\
$\mathrm{p}$ & 0.006 & 0.000 & 0.033 & 0.001 & \\
\hline
\end{tabular}


Regarding the frequency by sex, it was exhibited significant differences between male and female only in the type III and IV (Table II). No differences were found in the frequency of any age range with any classification of the tooth with the MSF (Table III).

In both first and second premolars, the average in the frontal plane for measurement A and B was significantly greater than in the sagittal plane (Table IV).

Table II. Frequency of type of relationship between premolar and MSF according to sex. T-test for independent samples.

\begin{tabular}{llllll}
\hline Sex & Type I & Type II & Type III & Type IV & Total \\
\hline Men & 8 & 22 & 40 & 20 & 90 \\
Women & 12 & 16 & 71 & 11 & 110 \\
Total & 20 & 38 & 111 & 31 & 200 \\
p & 0.636 & 0.076 & 0.004 & 0.017 & \\
\hline
\end{tabular}

Table III. Frequency of type of relationship between premolar and MSF according to age range. ANOVA test.

\begin{tabular}{clll}
\hline Measure & \multicolumn{1}{c}{ Sex } & \multicolumn{1}{c}{ Mean $(\mathrm{mm})$} & \multicolumn{2}{c}{$\begin{array}{c}\text { Standard devia } \\
(\mathrm{mm})\end{array}$} \\
\hline \multirow{2}{*}{ A $^{\prime}-$ Frontal } & Men & 3.67 & 4.71 \\
& Women & 5.78 & 6.27 \\
B' - Frontal & Men & 15.38 & 4.66 \\
& Women & 16.02 & 5.93 \\
A' - Sagittal & Men & 3.13 & 4.09 \\
& Women & 3.73 & 3.60 \\
B' - Sagittal & Men & 15.53 & 4.63 \\
& Women & 15.73 & 14.05 \\
\hline
\end{tabular}

Table IV. Mean and standard deviation of measure A' and B' in frontal and sagittal plane according to sex. T-test for independent samples.

\begin{tabular}{lccccc}
\hline $\begin{array}{l}\text { Age range } \\
\text { (yrs) }\end{array}$ & $\begin{array}{c}\text { Type } \\
\text { I }\end{array}$ & $\begin{array}{c}\text { Type } \\
\text { II }\end{array}$ & $\begin{array}{c}\text { Type } \\
\text { III }\end{array}$ & $\begin{array}{c}\text { Type } \\
\text { IV }\end{array}$ & Total \\
\hline $10-19$ & 9 & 8 & 44 & 6 & 67 \\
$20-29$ & 4 & 19 & 38 & 16 & 77 \\
$30-39$ & 3 & 4 & 10 & 3 & 20 \\
$40-49$ & 4 & 6 & 15 & 5 & 30 \\
$50-59$ & 0 & 1 & 2 & 0 & 3 \\
$>60$ & 0 & 0 & 2 & 1 & 3 \\
\hline Total & 20 & 38 & 111 & 31 & 200 \\
\hline p & 0.487 & 0.426 & 0.428 & 0.399 & \\
\hline
\end{tabular}

\section{DISCUSSION}

The present study analyzed the thickness of the BCB of the maxillary premolar teeth in conjunction with their proximity to MSF in Chilean volunteers.

Regarding the BCB thickness, the median values of the measurements showed values from 0.9 to $3 \mathrm{~mm}$, depending on the level, sex, and tooth analyzed. Previous studies analyzing the $\mathrm{BCB}$ of the same region found thickness values similar to the present study (Jin et al., 2012; Sathapana et al., 2013; Zekry et al., 2014; Khumsarn et al., 2016). The comparison of the BCB thickness of the maxillary premolar teeth at the five levels analyzed showed that the highest thicknesses occurred at the apical region (MA) in both sexes and in both premolars.

Other studies also reported significantly higher BCB thicknesses at the apical level (Park et al.; Jin et al.; Casseta et al., 2013; Khumsarn et al.; Temple et al., 2016), whose values exceeded $2 \mathrm{~mm}$, reaching up to $3 \mathrm{~mm}$ (Jin et al.), concurring with the results of this study. Also, the comparisons in the same level revealed that the BCB thicknesses in the same premolar between different sexes had greater values in male individuals, mainly in the apical tooth region (MA-MB). Previous studies comparing the thickness of the $\mathrm{BCB}$ of the upper premolar region in different sexes revealed in most of them (Adiguzel et al.; Fayed et al.; Jin et al.; Casseta et al.; Kang et al., 2015), that male individuals also have the thickest cortical bone. However, there are some reports that no significant differences were observed in the BCB thickness of the maxilla between sexes (Aktuna Belgin et al.; Sathapana et al.).

These data can be useful for the procedures of exodontia, when the preservation of the alveolar buccal bone is important for future rehabilitation with implants, that improve its prognosis; the data will also allow determination of thicknesses to be considered in the placement of microimplants in the premolar area.

On the other hand, regarding the position of the premolar apex and it proximity with MSF, it was observed that type III was the most prevalent position, while type I was the less frequent; this concurs with previous studies (Ok et al.; Kilic et al.). Kwak et al. (2004) reported that the distance between the apices of the first and second premolar with the MSF in frontal sections were $5.72 \mathrm{~mm}$. and $4.3 \mathrm{~mm}$, respectively, identifying variations of up to $50 \%$ higher, than our study for the second premolar.

It was observed that the distance between the apex of the premolars with MSF, decreases in the second premolar with respect to the first, which was supported previously by several authors (Ok et al.; Kilic et al.; Kwak et al.; von Arx et al., 2014; Estrela et al., 2016). In addition, the age ranges did not show significant results, possibly, due to the great dispersion of the sample.

The data of this study showed that the BCB of the upper premolar region is thicker in the apical region that 
decreases toward the coronal region, observing differences by sex in the apical region, while almost $50 \%$ of apex of second premolars are closely and risky related MSF (Type I and II), which sustains that the CBCT is a necessary tool before any intervention or plan in which premolar teeth are involved.

FUENTES, R.; ARELLANO-VILLALÓN, M.; SOTO-FAÚNDEZ, N.; ARIAS, A.; MONTIEL, I.; BORIE, E.; GARAY, I. \& DIAS, F Evaluación de la región premolar maxilar en relación con el piso del seno maxilar y la tabla osea vestibular: estudio de tomografía computarizada de haz cónico. Int. J. Morphol., 37(3):1079-1084, 2019.

RESUMEN: La localización del piso del seno maxilar (PSM) y la tabla ósea vestibular (TOV) son factores a considerar en el éxito a largo plazo de los tratamientos de implante dental en la región premolar. El objetivo de este estudio fue establecer características morfométricas del grosor de la TOV en los premolares maxilares y su relación con el PSM a través de CBCT. Se analizaron 350 primeros y segundos premolares en 110 CBCT y la TOV fue medida en vista coronal en el eje axial mayor de cada premolar. Además en 200 primeros y segundos premolares maxilares se midió la distancia desde el ápice del diente hasta el PSM en el plano sagital y frontal. El tipo de relación entre el ápice y el PSM se clasificó según Ok et al. (2014). El Segundo premolar obtuvo los mayores valores de grosor de TOV $(\mathrm{p}<0.001)$. En primeros premolares se observaron valores altos en el género masculino ( $p>0.05$ ). En segundos premolares solo se encontraron valores significativamente altos en el género masculino en MA-MB-MC ( $>>0.05)$. En la relación con el PSM y ápices de raíces de premolares, el $10 \%$ de la muestra se clasificó como tipo I, el $19 \%$ como tipo II, el 55,5\% como tipo III y el $15.5 \%$ como tipo IV. En conclusión la TOV de la región premolares superior es más grueso en la zona apical, decreciendo hacia la zona coronal. Alrededor del $50 \%$ de los ápices de raíces de premolares maxilares están cercanas y en relación de riesgo con el PSM (tipo I y II).

PALABRAS CLAVE: Premolar; Piso de seno maxilar; Tabla osea vestibular; Cone beam-computed tomography.

\section{REFERENCES}

Adiguzel, O.; Aktuna Belgin, C.; Falakaloglu, S.; Cangul, S. \& Akkus, Z. Maxillary cortical bone thickness in a south-eastern anatolian population: a cone-beam computed tomography study. Med. Sci. Monit., 23:5812-7, 2017.

Aktuna Belgin, C.; Adiguzel, O.; Bud, M.; Colak, M. \& Akkus, Z. Mandibular buccal bone thickness in southeastern anatolian people: a cone-beam computed tomography study. Int. Dent. Res., 7(1):6-12, 2017.

Buser, D.; Belser, U \& Wismeijer, D. ITI Treatment Guide. Implant Therapy in the Esthetic Zone - Single-Tooth Replacements. Berlin, Quintessence, 2007.

Casseta, M.; Sofan, A. A. A.; Altieri, F. \& Barbato, E. Evaluation of alveolar cortical bone thickness and density for orthodontic mini-implant placement. J. Clin. Exp. Dent., 5(5):e245-52, 2013.

Chen, S. T.; Darby, I. B. \& Reynolds, E. C. A prospective clinical study of nonsubmerged immediate implants: clinical outcomes and esthetic results. Clin. Oral Implants Res., 18(5):552-62, 2007.

Estrela, C.; Nunes, C. A.; Guedes, O. A.; Alencar, A. H.; Estrela, C. R.; Silva, R. G.; Pécora, J. D. \& Sousa-Neto, M. D. Study of anatomical relationship between posterior teeth and maxillary sinus floor in a subpopulation of the brazilian central region using cone-beam computed tomography - Part 2. Braz. Dent. J., 27(1):9-15, 2016

Fayed, M. M.; Pazera, P. \& Katsaros, C. Optimal sites for orthodontic mini-implant placement assessed by cone beam computed tomography. Angle Orthod., 80(5):939-51, 2010

Fuentes, R.; Flores, T.; Navarro, P.; Salamanca, C.; Beltrán, V. \& Borie, E. Assessment of buccal bone thickness of aesthetic maxillary region: a conebeam computed tomography study. J. Periodontal Implant Sci., 45(5):162-8, 2015.

Holmes, P. B.; Wolf, B. J. \& Zhou, J. A CBCT atlas of buccal cortical bone thickness in interradicular spaces. Angle Orthod., 85(6):911-9, 2015.

Jin, S. H.; Park, J. B.; Kim, N.; Park, S.; Kim, K. J.; Kim, Y.; Kook, Y. A. \& Ko, Y. The thickness of alveolar bone at the maxillary canine and premolar teeth in normal occlusion. J. Periodontal Implant Sci., 42(5):173-8, 2012.

Kang, S. H.; Kim, B. S. \& Kim, Y. Proximity of posterior teeth to the maxillary sinus and buccal bone thickness: a biometric assessment using cone-beam computed tomography. J. Endod., 41(11):1839-46, 2015.

Khumsarn, N.; Patanaporn, V.; Janhom, A. \& Jotikasthira, D. Comparison of interradicular distances and cortical bone thickness in Thai patients with Class I and Class II skeletal patterns using cone-beam computed tomography. Imaging Sci. Dent., 46(2):117-25, 2016.

Kilic, C.; Kamburoglu, K.; Yuksel, S. P. \& Ozen, T. An assessment of the relationship between the maxillary sinus floor and the maxillary posterior teeth root tips using dental cone-beam computerized tomography. Eur. J. Dent., 4(4):462-7, 2010.

Kwak, H. H.; Park, H. D.; Yoon, H. R.; Kang, M. K.; Koh, K. S. \& Kim, H. J. Topographic anatomy of the inferior wall of the maxillary sinus in Koreans. Int. J. Oral Maxillofac. Surg., 33(4):382-8, 2004.

Ok, E.; Güngör, E.; Çolak, M.; Altunsoy, M.; Nur, B. G. \& Aglarci, O. S. Evaluation of the relationship between the maxillary posterior teeth and the sinus floor using cone-beam computed tomography. Surg. Radiol. Anat., 36(9):907-14, 2014.

Park, M. S.; Park, Y. B.; Choi, H.; Moon, H. S.; Chung, M. K.; Cha, I. H.; Kim, H. J. \& Han, D. H. Morphometric analysis of maxillary alveolar regions for immediate implantation. J. Adv. Prosthodont., 5(4):494-501, 2013.

Pommer, B.; Ulm, C.; Lorenzoni, M.; Palmer, R.; Watzek, G. \& Zechner, W. Prevalence, location and morphology of maxillary sinus septa: systematic review and meta-analysis. J. Clin. Periodontol., 39(8):769-73, 2012.

Ryu, J.; Choi, S. H.; Cha, J. Y.; Lee, K. J. \& Hwang, C. J. Retrospective study of maxillary sinus dimensions and pneumatization in adult patients with an anterior open bite. Am. J. Orthod. Dentofacial Orthop., 150(5):796-801, 2016

Sathapana, S.; Forrest, A.; Monsour, P. \& Naser-ud-Din, S. Age-related changes in maxillary and mandibular cortical bone thickness in relation to temporary anchorage device placement. Aust. Dent. J., 58(1):67-74, 2013.

Temple, K. E.; Schoolfield, J.; Noujeim, M. E.; Huyn-Ba, G.; Lasho, D. J. \& Mealey, B. L. A cone beam computed tomography (CBCT) study of buccal plate thickness of the maxillary and mandibular posterior dentition. Clin. Oral Implants Res., 27(9): 1072-8, 2016.

Vera, C.; De Kok, I. J.; Reinhold, D.; Limpiphipatanakorn, P.; Yap, A. K.; Tyndall, D. \& Cooper, L. F. Evaluation of buccal alveolar bone dimension of maxillary anterior and premolar teeth: a cone beam computed tomography investigation. Int. J. Oral Maxillofac. Implants, 27(6):1514-9, 2012.

von Arx, T.; Fodich, I. \& Bornstein, M. M. Proximity of premolar roots to maxillary sinus: a radiographic survey using cone-beam computed tomography. J. Endod., 40(10):1541-8, 2014

Zekry, A.; Wang, R.; Chau, A. C. \& Lang, N. P. Facial alveolar bone wall width - a cone-beam computed tomography study in Asians. Clin. Oral Implants Res., 25(2):194-206, 2014

Corresponding author:

Prof. Dr. Ramón Fuentes Fernández

Research Center for Dental Sciences

Dental School, Universidad de La Frontera

Av. Francisco Salazar 01145

Temuco - CHILE

Email: ramon.fuentes@ufrontera.cl

Received: 07-01-2019

Accepted: 05-04-2019 